\title{
1 Culture of Mayurbhanj and Medinipur : A Comparative Study
}

Mukteswar Das, Assistant Professor \& H.O.D (Department of History), Ramnagar College,V.U, W.B. Research Scholar, North Orissa University, Takatpur, Mayurbhanj, Odisha.email: mukteswardas@gmail.com

\begin{abstract}
Mayurbhanj and Medinipur are the districts of two neighbouring states Orissa and West Bengal in India. Mayurbhanj, a tribal-dominated district, bounded on the north by Singbhum District of Bihar and Medinipur District of West Bengal, on the south by the state of Keonjhar and Balasore District of Odisha, on the east by the districts of Medinipur and Balasore and on the west by Singbhoom and Keonjhar, has an area of 10,418 square kilometres. ${ }^{1}$ Medinipur, a caste dominated district, bounded in the north by Bankura district, on the east by Hughi and Howrah districts, on the south by Bay of Bengal, on the southwest by Balasore district, on the west by Singbhum and Mayurbhanj districts and on the north west by Purulia district has an area of $14,081 \mathrm{sq} . \mathrm{km} .{ }^{2}$ People of both the districts have a close cultural contact since time immemorial. A number of people of each district live one another's area and make family relationships in spite of their difference in official language and lifestyle. Therefore the objective of this paper is, to find out such differences and similarities as well as nature of assimilation in the culture of the people of both the districts through proper comparison.
\end{abstract}

Key Words: Mayurbhanj, Medinipur, culture,

\section{Introduction}

Culture reveals the language, literature, rites and morals, religion and religious ceremonies and the artistic activities of the people. Besides, folklore is an important aspect of culture which explains peoples sociocultural system, beliefs, values and attitudes through the folk tale, folk songs, folk dance, legends, fairs and festivals, religion, superstitions, customs and traditions. ${ }^{3}$ Taking a few characteristics of culture as language, religion and religious ceremonies, fairs and festivals, folk songs and folk dances of the tribes and Hindu castes of both the districts, the researcher has compared their "design of living" in this paper. 


\section{(C) Mukteswar Das}

\section{Language}

In the cultural arena, it is seen that in Mayurbhanj, the non-tribes speak Odiya and the tribes speak Munda group of languages consisting of Santali, Ho, Mundari, Bhumiji, Mahali, Kera, Karmali and Karua. In Mayurbhanj, in the 1951 census, the number of languages was 23 but in 1961 census it became 24. About 20,171 persons spoke Bengali as the mother tongue. The Kurmis speak a mixed language of Hindi, Bengali and Oriya. ${ }^{4}$

Some tribes also speak the broken form of Odiya language. The Santali with their script Olchiki is popular in Mayurbhanj. Pandit Raghunath Murmu is regarded as the father of Olchiki script. Likewise, Mundari script has invented by Pandit Rohidas Sing Nag of Salbani of Mayurbhanj. Various courses of study books are also published in Mundari script named 'Mundari Bani Puthi' published by Bharat Munda Samaj(BMS), Central Unit, Baripada. ${ }^{5}$ Similarly, Hoo as Kolha language, Kulilipi as Kondh language, Soradam Sompeom as Sauru language are in vogue in the tribal society. ${ }^{6}$

Generally, two types of languages are spoken by the people of Medinipur. One of them is sub language of Bengali which called manya (accepted) and another is Standard Colloquial Bengali (SCB) Which is spoken language of the people of different regions of this district by which they communicate with their family members, relatives and neighbours. In case of education, administration and delivering lecture outside of its community they use accepted the Bengali language. In both cases, the pronunciation process of the people of different region and castes seem to be different.

To get a primary idea regarding this variation an example is given here.

Manya Chalit Bhasa Anchalik Kathya Bhasa Prachalaner Anchal

(Accepted traditional language) (Regional spoken language) (Area of use)

$\begin{array}{lll}\text { Chhele(Boy) } & \text { Chhele } & \text { Ghatal,Chandrakona } \\ \text { Do. } & \text { Chhua } & \text { Ramnagar } \\ \text { Do. } & \text { Kuna } & \text { Binpur } \\ \text { Do. } & \text { Chanka } & \text { Panskura } \\ \text { Do. } & \text { Chhyana } & \text { Pingla,Debra } \\ \text { Do. } & \text { Toka } & \text { Nandigram,Khejuri. }\end{array}$




\section{(C) Mukteswar Das}

Such types of variations are also seen even at villages too. A small village named Sarisa of P.O. Paniparul, P.S. -Egra, some people express the word 'why' as kene, and some as keni; 'I' as aame, mu, mui etc. 'me' as aamku, mote, moke etc. ${ }^{8}$ In the census report of 1921, Mr.Thomson referred to such language as 'a hybrid language, with something of Oriya in it'. ${ }^{9}$ Beside Bengali and Odiya, the tribes of Medinipur district use Kherwari language as Santali, Bhumij, Mundari, Kora etc. Urdu is spoken by the elite Muslims and the others of this religion speak in both Urdu and Bengali. People who have come from North West speak in their own language i.e. Hindi. A vagabond class named Kagmara speaks in Telegu whereas the Shialgirs of Datan use Gujrati as their spoken language. ${ }^{10}$

\section{Religion and Religious Ceremonies}

Hindu, Muslim, Christian, Sikh, Buddhist, Jain and some religion which mentioned in others category in the census of 2011 are found in Mayurbhanj. Here, the majority of people are of Hindu religion. Muslim and Christian are in the $2^{\text {nd }}$ and $3^{\text {rd }}$ place respectably. In the 1961 census the number of Muslim was 7,557 and Christian were 870 . On the eve of the $20^{\text {th }}$ century, there were some followers of Brahma Samaj at Keonjhar of Mayurbhanj. In 1951 census, Kumbhipotias are included as 'Other Non-Tribal Religion' who were the followers of Alekh Gosain and used to worship the Sun as a branch of Mahima religion. ${ }^{11}$

In case of Hindu religion, various deities like Salta, Sakta, Saiva, Vaishnava and Ganapatya sects are found at Khiching of Mayurbhanj wherefrom it is assumed that Hinduism was in vogue more than a thousand years ago. Moreover the worship of Siva, Sakta and Vishnu are prevalent here even today. Many temples of Lord Siva are seen in this district. Thakurani named village deity is worshipped in almost every village here. Though the district is tribal oriented, with the passage of time most of the tribes are influenced by Hinduism. ${ }^{12}$

The tribes of Mayurbhanj believe in many deities. To them the Sun is omnipotent, creator and father and Earth is the mother. All others are their offsprings. Sun is worshipped by different tribes in different names. Santals worship him as Thakur Jiu', Sin Bonga or Dhorom. To Santals, the chief presiding deity is 'Marang Buru'. Like Maran Buru the other village deities are Moneko Turiko, Jaher Era and Gosain Era. The said deities reside under a holy grove which is called Jahera placed on the outskirts of the village. Such deities play important socio-economic roles in the life of this tribe. Other important deities of the Santals are Manjhi Bonga, Abge Bonga, Hapranko Bonga, Rango Bonga and Basumata or mother earth. The village head man of the Santal is called Manjhi. It is believed that Manjhi Bonga has stayed in the 


\section{(C) Mukteswar Das}

front side of the house of Manjhi. Abge bonga is regarded as household spirit. Santals worship Hapranko Bonga as ancestral spirit, Buru Bonga as hill deities and Rango Bonga as forest deities. ${ }^{13}$ The Santals follow certain rituals to appease the deity. They accept the Dehuri as their village priest. They believe in spirit, ghosts, and many superstitions. The Gonds worship the deities as Jangadeo, Lingadeo and Buradeo. They have some household deities as Jhulan Devi etc. The nature worshipper Kolhas worship Sinbonga (creator of the universe)and his wife Nagbenga and Basuli etc. ${ }^{14}$ Besides, Singabonga, a number of other deities are worshipped by the Bhumijas as Dharma (the son of Singabonga), Baguti (Bana debata or forest god), Goria(Tree God, like Mahua tree), Baguli (the God who watches their cattle in forest), Goram (a goddess who protects the village), Buru Bonga (god of the grove of the village), and Istha (their ancestors). ${ }^{15}$ The Lodha community worship 'Dharma Devta'(the god of righteousness), Goddess Basumati(mother earth), Sitala as a chief deity (Goddess of epidemics like cholera and smallpox etc.), Manasa (goddess of the snake) etc. ${ }^{16}$

Besides, the worship of own tribal deities, the worship of a number of Hindu deities is begun to be worshipped by the Kolhas. The conception of Bishnu and Laxmi as the god of protection and the goddess of fortune are well known to the Kolhas. They worship another goddess named Devi Maa. A large number of Kolhas returned as Hindus. They worship Kali, Kichakeswari etc. though their own Gods are Marang Bunga, Hmbok, and Dwarsuni. They worship the spirits of their ancestors too. The worship of cow evidently has been directly borrowed from Hindus. The nature of observance of Dasai and Phagu festivals of this tribe are as similar as the observances of Dushera $\&$ Holi of the Hindus. ${ }^{17}$

Vedic gods like Krishna, Shiva, Durga etc. the folk deities as Manasa (goddess of the snake), Dharma Thakur, Sitala(goddess of pox), Sasti (Goddess of protector of the child), Chandi (goddess of welfare of the people), Panchanan(goddess of protector of the child), Panchuthakur (protector of the child), Kalu Roy(protects from tiger and crocodile), Ateswar (God of evil spirit), local and village-based deities, are worshipped by the Hindus of Medinipur. Among tribal people of these districts, baram and sini named different types of deities are also worshipped.$^{18}$

The worship of tribal deities and their religious ceremonies are also seen in Garbeta, Shalbani, Binpur, Jhargram etc. of Medinipur. The worship of goddess Baram is done under the trees by the priests of their own class. At night of Poush Sankranti and on the first day of the month of Magh the annual worship of this goddess is held. Such worships are held in the different areas of Medinipur city. 


\section{(C) Mukteswar Das}

The people of barna hindu classes are also given financial help for this worship and attend their puja pandel. Generally, this worship is very popular among Santal, Lodha, Bauri and Mahali.

The said people pray to the god in the following way.

"Bal-bachhader mongal karo thakur

Gerame jeno asukh bisukh na hoy,

Marak na lage, Bagh valluk dauratya na kore,

Ebare ei dichhi man tusti kore khao.

Aschhe bachhar benche raile abar debo.

Amader manaskamona purna karo thakur."

It means O Lord, do well to our children so that no illness attack in the village, no epidemic happen, no attack come from tiger or bear. This time accept this offer with content. Next time, if alive, we will offer you again. O lord fulfil our desire. ${ }^{19}$

Beside Baram different named Chandi like Baram Chandi, Joy Chandi, Bhairabi Chandi etc., Sitalamata, Basumata and Dharam Devta are worshipped by the Lodhas. ${ }^{20}$ The principal god of the Kharias is Girin or Bero Devta who is also regarded as Thakur by many of them. Other deities are considered as his children. Kharias also believe that God resides in every mountains and hill. For this, they named their gods in the names of mountains. As god Dalmapat is named in the name of a hill called Dalmapahar. According to them, mountains control over storm and rain. To them, Garam is the village god and Dharam is the house god. ${ }^{21}$

Most of the Bhumijs obeys Hindu deities. In spite of this, they worship Sinbonga or Sun god, Garam Thakur as Village god (worshipped on the month of Baishakh) and Garai Thakur (worshipped on the month of Kartik). In expectation of increasing domestic animals like cow, they worship Garai Thakur. Baghut is also worshipped on the month of Kartick as the saviour from the attack of wild beasts. Besides, they also worship other deities like Jahir Buru, Dharam, Kudra or Bisay Chandi and Panchbahini. ${ }^{22}$

Like Baram, the worship of goddess Sini is done under the trees. The persons who act as the priests are called Layek and Deshwalis. Sini is worshipped in different names. These are Nachanjamsini, 


\section{(C) Mukteswar Das}

Machaisini, Shikrasini, Rupasini, Jharbanisini, Balibilasini, Halyasini, Ghagrasini etc. As protector of the village and giver of good corns, she is worshipped annually by the villagers on the first day of the month of Magh offering a little useful thing. There is no tradition of using chants in this worship. Generally, the tradition of slaying beasts is seen in this worship. ${ }^{23}$

\section{Fairs and Festivals}

The chief festivals of the Hindus of Mayurbhanj are Akshay Tritiya, Makar Sankranti, Gamha Purnima, Nuakhai, Uda Parab, Karam festival, Budhi Bandna, Car festival etc. ${ }^{24}$ Besides, Shivaratri, Rasa Jatra, Dasahara, Kali-Puja, Holi, Chandan, Inda Jatra, and Kukuda Uda are observed here. With this, Jagadhatri Meela at Bhanjapur, worship of Maa Ambika of Badabazar, Bali Yatra, Durga puja at Baripada are praise worthy in Mayurbhanj.

The significant festivals observed by the Santals of Mayurbhanj are Erok-sim Harihar-sim, Iri guldi sim, Janthar, Saharas, Maga-sim and Baha. Such festivals are connected with agricultural activities. Erok-sim is held at the outset of sowing the seeds in the fields. Harihar-sim is celebrated in the time of growth of the seedlings. Iri-guldi sim is arranged for the offering of the first millet crop. Jantal 'is a celebration of the first fruit of the winter rice crops'. Magh sim is celebrated in the month of Magha(JanuaryFebruary).It marks the end of the year. During Baha festival, the Santal offers to the Jaher, the first fruit of Mahua tree, wildflowers and fruits. Bonga worship is mainly done out of fear. ${ }^{25}$

Fairs and festivals of Medinipur are very attractive. The festivals of shivachaturdasi, charak, dharmathakur of Moyna, barunimela of Tamluk, fairs and festivals of pousparban, rathayatra of Mahisadal, rasutsab o mela, dol fairs and festivals of Bogri Krishnanagar, great danda fair and festivals of Gopiballavpur, fairs and festivals of bhim worship etc are notable. The said worships of the deities, fairs and festivals of the tribes and other religions, also make an effect on the people and their culture of this District. $^{26}$

Like Hindus, the tribals also observe many festivals. These are Jathel (celebrated by the Lodhas on the month of Ashara seeking blessing from their god, before the beginning of cultivation), Jaoa Parab (observed by the Lodha, Bhumij and other tribes on the month of Bhadra as an agrarian festival which specially held in the time of seedling of corns), Baha Parab, Badhna Parab etc. ${ }^{27}$ 


\section{Folk Songs}

One of the valuable parts of the people's life is their song through which they express their desires, their weal and woe. There are eight types of a song seen among the Lodhas of Mayurbhanj as Jhumur song, Marriage song, Bandna song, Tusu song Kathi nach song, Doli song, Changu song and Jant. ${ }^{28}$ Like Lodhas, the Kharias play Raja Doli and sing the Doli songs. Doli songs are simply sweet and heart touching. One of them is:

\section{"Ambada Dharila Kasi \\ Chalabaripada debi Arasi \\ Munda Khanku Thibu Basi."}

It means the boy is calling his girlfriend to go to Baripada where he would purchase a mirror for her so that she could comb her hair in the house sitting before the mirror. ${ }^{29}$

The culture of classical loud song beside various folk songs is conventional in Medinipur. Dhrupada, Dhamar, Kheal, Shyamasangeet etc. are inclined to classical loud music of Medinipur which are not separated from Hindustani Music. Chandrakona was the first pathfinder in classical loud music in Medinipur. ${ }^{30}$ Beside Classical loud Music, Kirtan is citable in Medinipur. Both Nam kirtan and Lila kirtan are seen here. Like kirtan many folk songs are popular in this district. Kabigan, Mangal gan and Jhumur are representative art here. Its appeal, crossing the boundary of this district, attracted the art and literature of Bengal. ${ }^{31}$

A class called Patua is seen in West Bengal's Medinipur district who painting pots(picture) on clothes or papers go to the door to door and sings related songs of their painted pot and earn money. Though the songs would not properly be related to their picture, an ancient religious story a related matter of the Hindus as Behula-Laxminder, Manasa related, Ramayana related, Bhagwat related as well as Conch wearing of Devi Parbati, Kamale Kamini (siting gesture of Goddess Laxmi on lotus), Gouranga lila (story of activities of lord Gouranga), Gosain pot, Saheb pot, Dakater pot, Yam pot etc. are seen in their pictures. Basically religiosity and mythology are mixed within patua song where a heart touch feeling of Bengali life have been revealed. ${ }^{32}$

Tusu, Bhadu, Bandhna, pata, marriage song, karam dance and song, jhumur, ahira, bandana gan and song for cultivation are the principal songs in the folk songs of Medinipur. A large number of Santals are 


\section{(C) Mukteswar Das}

found in West Medinipur and Jhargram. Scholars have classified Santali song into three categories. These are religious ceremony related song, social programmes related song and secular song. Some subcategories are also seen in the religious ceremony related songs of the Santals as Baha, Ma:Morde, Karam and Saharai. ${ }^{33}$ Like the tribal song, the other folk songs of the people of Hindu castes are also notable. For example, a song from Bans Paharir Lokosangit, is referred here. It was written and sung by a man in the village of Banspahari of Medinipur named Haradhan.

"Guru,Janam Dukhir kapal manda ami ekjana,

Amar dukhe dukhe janam gelo,

Amar dukha bine sukh holo na." ${ }^{34}$

Here, the singer laments for his misfortunes as there is no happiness in his life.

\section{Dance}

There are good numbers of dance forms found in Mayurbhanj. These are Chhau, Jhumar, hangu dance, Monkey dance, Panta Naach, Kathi Naach etc. The chhau dance of Mayurbhanj has recognized as the Heritage of World by UNESCO.$^{35}$ In this dance system, generally, the dancers dance in an open place and do not sing the songs. The singers sing the song playing musical instruments behind the screen. At Baripada an open Chhau Pandel is there where the annual Chhau performance takes place on the occasion of 'Chaitra Parva'. It is also known as 'Basanta Utsav' (Spring festival). In any form of dance of Chhau, the artist come to the pandal in heroic posture. Then gradually they move their toes and perform dance according to the demands of the character and tune of the music. After the dance is completed the artists leave the pandel (stage)with backward steps by looking to the audience and go back to their resting place. Dhol, Mahuri, Chadchadi, Dhumsa and Madal are used as musical instruments in this dance. ${ }^{36}$

Jhumar and Chhou dance are a combination of tribal and non-tribal combinations. Another dance style Chhangu is performed by the Khairas before their village deity Badam on the festive occasion. At the beginning of this dance style, the rhythm of change is slow and it becomes speedy thereafter. During the dance span they forget even their child which reveals through the following rhythm:

"Chhai ghini ghini chhai

Chhai ghini ghini chhai

Chuaku pakei makei ghin." 


\section{(C) Mukteswar Das}

It means, keep the baby on the ground and come to dance with me. ${ }^{37}$ Monkey Dance is performed in the occasion of Makara as 'Galienage'. 'Karam nat' is a popular dance form of the Bhumijas. ${ }^{38}$

Many types of folk dances are in vogue in Medinipur as chhau, pata, paik, chang or changu, jhumur, Kali's, Boljha sudhar sai, Bhuan, Kathi, Bagh, Khemta etc. Chhau dance has been performing at Chilkigarh and Debra of Jhargram subdivision even today. Cultivators of Chilkigarh when dance and sing roundly in a group stepping their feet with the rhythm of Madal, is called Pata Nach(dance). Such dance is prevalent in the Bhumij, Santal, Kurmi Mahato and even the common cultivators of Chilkigarh, Sadar subdivision and many villages of Jhargram. Somewhere Jhumur song is sung with this dance. This dance is in vogue haludbari's tahundanga field of Jambani P.S on the occasion of Badhna Parab. Paik dance is nothing but war dance where the dancers show some physical exercises and play with lathi(stick), sarki (a tool used for hunting) and taloar (sword) and sing in time of dancing.simultaneously with songs. Such dance troops are seen around Lodhsuli. Changu dance performed by ringing an instrument called change. Changu is an on round-shaped wheel type instrument. It is seen at the western part of this district. Jhumur dance is in vogue at Garbeta of West Medinipur.

In West Bengal, Tusu and Bhadu songs are sung following the tunes of Jhumur in many times. On the occasion of Gajan festival at Mahishadal, Kathi Naach is shown at the dawn of Nilratri. Boljha Sudharsai dance is performed with agamoni song of Sharadia festival on the month of Ashwin at Garbeta. Bhuang dance is performed at Chilkigarh in time of the worship of Kanak Durga. Kathi Nach is seen at Goaltor of Garbeta in the month of Ashwin in the occasion of worship, Jambani and Jhargram of Medinipur. Khemta nach (dance) was prevalent in the time of the Zaminders (landlord). It was similar to the dance of the then baijis (prostitutes). Now a day it is seen as group dance at Garbeta, Medinipur. ${ }^{39}$

\section{Findings and Conclusion}

Though 53 types of tribes are identified in Mayurbhanj out of 62 types of tribes in Odisha, a number of tribes, officially 18 in number out of 38 of West Bengal is also found in the district of Medinipur. Their diversity in language, nature of worship, celebration of different fairs and festivals, recreation like the song and dance is praiseworthy. But in many cases due to the impacts of Oria culture in Mayurbhanj and Bengali culture in west Bengal, there is some differences in spite of many similarities found in the above discussion. 


\section{(C) Mukteswar Das}

In the case of language, it is seen that besides official language there are a number of mixed languages seen in both the districts. The Santali script, Olchiki invented by Pandit Raghunath Murmu of Mayurbhanj.It has been officially accepted in both the districts of Mayurbhanj and Medinipur, But, Sadhu Ramchand Murmu of West Medinipur is regarded as 'Kabiguru' in Santali literature. He showed the first effort of it by making several scripts named 'Maj dader Ank' in 1923 A.D. In an essay published in Ananda Bazar Patrika on $15^{\text {th }}$ Bhadra in 1377 B.S, the writer wrote "Sadhu Ramchand of West Bengal and Raghunath Murmu of Orissa has created Santali alphabets separately. The alphabet created by Sadhu Ramchand is unknown to Santal society and due to dearth of money its publicity by making blocks of the script have not been possible. This alphabet is older than Raghunath Babu". Such information proved that the effort for making script started from both the districts of India. ${ }^{40}$

In the case of religious belief, both the people from tribal and non-tribal classes have been worshipping different forms of superpowers. Sometimes by making an imaginary image of clay, different trees, stones or different forms of nature have been worshipped in this expectation that their desires as getting good harvest, different illness and phobia free life could be fulfilled. Besides, through worship, they have been tried to satisfy some powers so that no harm done from their sides. In the case of fairs and festivals, it has been seen that the rigidity in religious bondage is lightening day by day. Now a day, most of the people are enjoying and even participating in one another's culture. As for example, in Mayurbhanj, the Bathudis observe Hindu festivals like Dol Purnima, Raja Sankranti, Dashara Prathamastami etc., The Gonds worship Hindu gods like Jagannath, Krishna and Ram. ${ }^{41}$ The Kharias worship Basumata (as Earth goddess), Ganesh, Baruna, Kali, Duarsuni, Murmuriani etc., ${ }^{42}$ Bhumijas of Mayurbhanj observe Raja sankranti, Gamha Purnima, Makar Sankranti, Nua Khia etc., like the Hindus. In case of marriage and death rites, they call Brahman priests. But for worshipping their traditional deities, they call Dehuri, the priest of their own caste. ${ }^{43}$ In Medinipur, the Bhumijs also follow such cultures of the Hindus but with a little bit of difference. As just before the day of Poush Sankranti, they do worship which is called Maroi Puja like the Hindus. It is done at night when the fox calls. It is believed that from the side wherefrom the fox calls, is fit for good production. After this day, in Poush Sankranti, the Bhumijs adorn new clothes which are not prevalent among the Hindus. In the case of marriage and death rites the Bhumijs of Medinipur also called the Brahman priest who is fixed by their community. If the fixed personal fails to come, he may send another Brahman. No bhumij is allowed to call any Brahman priest personally other than the fixed one for doing worship. ${ }^{44}$ 
In case of the religious festival, the Baishnabs of Mayurbhanj come to attend the great Danda Mahotsab of Gopiballavpur. ${ }^{45}$ Srichaitanya of Medinipur of Nadia, W.B, visited Haripur in his way to Puri. Badauni the famous chroniclers mentioned in his account that the road from Bengal to Puri passed through Haripur. ${ }^{46}$ The Baishnab guru(religious teacher) of Medinipur, Shyamananda and his disciples spread Vaishnavism in Mayurbhanj in the Medieval age. All the family members of Baidyanath Bhanja, the mighty king of independent Mayubhanj State, initiated in Vaisnavism by Shyamananda. ${ }^{47}$ Maharaja Baidyanath Bhanja constructed Rasik Roy Temple for the worship of Lord Krishna. ${ }^{48}$ Since then the Mohanta Goswami family of Gopiballavpur was honoured by the members of the bhanja kings as guru. In case of marriage, sraddh, investiture, worship and festivals, the members of the Kings family invite them and obey their direction. Beside religious matter, The Goswami family of Gopiballavpur played their roles in political matters also. In a time of second Anglo -Maratha war, to keep the support of Mayurbhanj, the British East India Company urged to Bikramananda, the $5^{\text {th }}$ Mahanta of Goswami family, to make a settlement in the discontent of Sumitra Devi and her adopted son Tribikram Bhanja. ${ }^{49}$ The Bhanjas made Haripur as a great centre of Vaishnavism. ${ }^{50}$ A number of tribal who were socially deprived and tortured by the upper castes were initiated Baishnavism during this period. The Baishnab sankirtan are so popular still today among such people of Mayurbhaj that it is heard spontaneously during the religious programme specially held on the month of Baisakh. ${ }^{51}$ The blending of tribal and non-tribal culture is seen in both the districts as in the Shaktipitha at Khichhing of Myurbhanj, the Brahmin priests and Bhuian Dehuris enjoy equal rights of worship of Khijjingeswari and there is no discrimination for offering Puja(worship) in the temple. ${ }^{52}$

Beside similarities and assimilation in culture, some differences are also seen in the people of the study area. Though the Chhau dance of Mayurbhanj is very popular than Medinipur the Chhau performance of Jhargram, Belpahari, Chilkigarh and Dubra village etc. of Jhargram division cannot be neglected. The difference of this dance performance is seen in both the district. No mask is used in the said dance performed at Baripada but in Medinipur's Chhau dance that are performed at Chilkigarh King's palace is performed by wearing masks. ${ }^{53}$ Besides, the celebration of ratha yatra is seen in both the districts but at Baripada of Mayurbhanj, the chariot of Subhadra is pulled only by the women which is not in vogue in Medinipur. ${ }^{54}$ Likewise patua song of Medinipue is not prevalent in Mayurbhanj. 


\section{References}

1.Chhatish Chandra Dhal, Tribal Peasant Unrest: A paradox in welfare Administration, New Delhi, 2012 , p.7.

2.Binod Shankar Das and Pranab Roy(ed.),Medinipurer Itihas $O$ Sanskritir Bibartan,Vol.I.Sahityalok,Kolkata,1989,p.14.

3.Jatindranath Singhdeb Sachan, The Lodhas of Mayurbhanj Eastern India, Aayu Publications, New Delhi, 2018, p.32.

4.N. Senapati and N. K. Sahu, Orissa District Gazeteers, Mayurbhanj, Cuttak, 1967, pp.106 and 113.

5.Vide article of Pradip Kumar Sahu, Changing Socio-Economic and Cultural Profile of Bhumij Tribe of Mayurbhanj, published in the Proceedings of National Seminar, edited by J.N.S.Sachan,B.B.College,Baiganbadia,Mayurbhanj,2011,p.86.

6.Vide article of Manmohan Das and Subhendu Das, Tribal Religion and Culture of Mayurbhanj, published in the Proceedings of National Seminar, edited by J. N. S. Sachan, B.B. College, Baiganbadia, Mayurbhanj, 2011,p.39.

7.Kamal Choudhuri, Medinipurer Itihas,Part I, Dey’s Publishing,Kolkata,2014,pp.457-461.

8.The author made an interview with Narendranath Bhanja of Vill. Sarisa, P.s-Egra of East Medinipur and collected the fact on 10.12.2018.

9.Yogesh Chandra Basu, Medinipurer Itihas, Vol. II, , edited by Pranab Roy, Orient Press,Kolkata,1416 B.S ,p.421.

10. Ibid. pp.422-423.

11. Tara Datta(ed.),Odisha District Gazetteers, Mayurbhanj, Gopabandhu Academy of Administration,(Gazetteers Unit),2016,pp.112-115.

12. Ibid. pp. 112-114.

13. Tribes of Orissa, Published by ST and SC Research and Training Institution, Bhubaneswar, 2004, pp.269-270.

14. Manmohan Das and Subhendu Das, op. cit. p. 39.

15. Pradip Kumar Sahoo, op.cit.p.87. 


\section{(C) Mukteswar Das}

16. Vide article of Subhas Chandra Das, Life of the Lodha-A Primitive Tribe of Mayurbhanj, published in the Proceedings of National Seminar, edited by J. N. S. D. Sachan, B. B. College, Baiganbadia, Mayurbhanj, 2011,p.36.

17. Vide the article of Ashok Priyadarshi, The Kolhas of Mayurbhanj: Their identity and Transformation, published in the Proceedings of National Seminar, edited by J. N. S. D. Sachan, B.B.College,Baiganbadia,Mayurbhanj,2011,pp.73-74.

18. Binodshankar Das and Pranab Roy (ed.) Medinipurer Itihas O Sanskritir Bibartan, Vol. II, Sahityalok, Kolkata, 1998,pp.353-365.

19. Prabodh Kumar Bhaumik, Amader Medinipur, Book Trust, Kolkata, 1997, pp.26-29.

20. Dhirendranath Baskey, Paschim Banger Adibasi Samaj, Vol. I, Baskey Publication, Kolkata, 2006, p. 49.

21. Ibid, p. 69.

22. Ibid, pp. 99-100.

23. Pradyot Kumar Maity, Medinipurer Lokasanskriti, Pustak Bipani, Kolkata. 2015, pp. 44-45.

24. Lipika Behera, Major festivals of Mayurbhanj, The Reasarchers, Vol.III, Issue-II, December, 2017, pp.32-38.

25. Tribes of Orissa, op.cit. p. 270.

26. Tarundeb Bhattacharya, Paschim Banga Darshan, Medinipur, Firma K. L. M. Ltd, Kolkata, 1979,pp.94-100.

27. Pradyot Kumar Maity, op.cit.,pp.70-72

28. Jatindranath Singhdeb Sachan, op.cit. p.45.

29. Vide article of Jatindranath Singhdeb Sachan, Socio-Economic and Cultural Profile of the Kharias of Mayurbhanj, and Published in the proceedings of National Seminar, edited by J. N. S. D. Sachan, B. B. College, Baiganbadia, Mayurbhanj, 2011, p.25.

30. Pranab Roy and Binod Shankar Das(ed.),Medinipur Itihas O Sanskirtir Bibartan, Vol. III, sahityalok,Kolkata,2002, ,p. 223.

31. Ibid. pp-250-252.

32. Prabhat Kumar Goswami, Bharatiya Sangiter Katha, Adinath Brothers,Kolkata, 2011, p.325.

33. Binodshankar Das and Pranab Roy, Vol.III, op. cit., pp. 380-381.

34. Binodshankar Das and Pranab Roy, Vol. II, op.cit. p.178. 


\section{(C) Mukteswar Das}

35. Vide article of Ananta Kumar Jena, Heritage of Mayurbhanj-A Special Reference to the Chhau Dance, Published in the proceedings of National Seminar, edited by J. N. S. D. Sachan, B. B. College, Baiganbadia, Mayurbhanj, 2011, p.50.

36. Ibid. p.53.

37. Vide Article of Jatindranath Singhdeb Sachan, op.cit. p. 27.

38. Vide Article of Manmohon Das and Subhendu Das, op.cit.p.45.

39. Pradyot Kumar Maity, op.cit. Pp.133-138.

40. Parimal Hembram, Saontali Sahityer Itihas, Nirmal Book Agency, Kolkata, 2007, pp.155156.

41. Manmohon Das and Subhendu Das, op.cit.p.39.

42. Vide the Article of J.N.S.D.Sachan, Socio-Economic and Cultural Profile of the Kharias of Mayurbhanj, op.cit.p.27.

43. Vide the Article of Deepak Sarangi, Changing,Socio-Cultural Economic Scenario of the Tribal Society of Mayurbhanj, Published in the proceedings of National Seminar, edited by J.N.S.D.Sachan,B.B.College,Baiganbadia,Mayurbhanj,2011, .p.9.

44. The author made an interview with Khokon Singh of Belda, Paschim Medinipur and collected the fact on 8.12.2018.

45. Binod Shankar Das and Pranab Roy, (ed),Medinipurer Itihas O Sanskritir Bibartan,Vol.II, op.cit., ,p.320.

46. Vide Article of Jatindranath Singdeb Sachan, Historical Identity of Mayurbhanj State: An Overview, Published in the Proceedings of National Seminar, organized by Department of History, Government Women College, Mayurbhanj, 2015, p.32.

47. Binod Shankar Das and Pranab Roy, (ed), Medinipurer Itihas O Sanskritir Bibartan, Vol.II, op.cit. p.384.

48. Vide Article of Jatindranath Singhdeb Sachan, Historical Identity of Mayurbhanj State: An Overview,op.cit.p.32.

49. Binod Shankar Das and Pranab Roy,(ed), Medinipurer Itihas O Sanskritir Bibartan,Vol.II, op.cit. , p.384.

50. Probodh Kumar Mishra, Archaeology of Mayurbhanj, New Delhi, 1997, pp.22-23.

51. The author made an interview with Jatindranath Singhdev Sachan of Baripada, Mayurbhanj and collected the fact on 25.01.2019. 
The Researchers' - Volume VI, Issue I, 10 March-2020

International Research Journal (Double-blind peer-reviewed)

Date of Acceptance : 12 November 2019
ISSN : 2455-1503

Impact Factor - 3.635

DOI - 10.21276/tr.2020.6.1.AN1

(C) Mukteswar Das

52. Vide Article of Deepak Kuma,R Sarangi, op.cit. p.9.

53. Pradyot Kumar Maity, op.cit. p.133.

54. Lipika Behera, op.cit.,p.56. 